IRA-International Journal of Applied Sciences ISSN 2455-4499; Vol.05, Issue 01 (2016)

Institute of Research Advances

Pg. no. 40-56

http://research-advances.org/index.php/IRAJAS

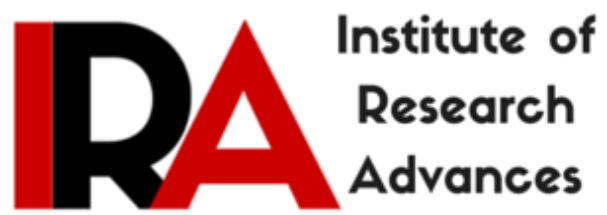

\title{
An Evaluation of the Antioxidant Status and Antimicrobial Activity of the Methanol Extract of Ocimum Gratissimum
}

\author{
Sajini Souda ${ }^{1}$, George Saramma ${ }^{1}$, Irene Goercke ${ }^{2}$, Kelvin Chabaesele ${ }^{3}$, Naledi \\ Mannathoko ${ }^{1}$ \\ ${ }^{1}$ Faculty of Medicine, University of Botswana, Gaborone, Botswana. \\ ${ }^{2}$ School of Allied Health Sciences, Faculty of Health Sciences, University of Botswana, \\ Gaborone, Botswana. \\ ${ }^{3}$ Department of Biological Sciences, University of Botswana, Gaborone, Botswana.
}

Type of Review: Peer Reviewed.

DOI: http://dx.doi.org/10.21013/jas.v5.n1.p7

\section{How to cite this paper:}

Souda, S., Saramma, G., Goercke, I., Chabaesele, K., \& Mannathoko, N. (2016). An Evaluation of the Antioxidant Status and Antimicrobial Activity of the Methanol Extract of Ocimum Gratissimum. IRA-International Journal of Applied Sciences (ISSN 24554499), 5(1), 40-56. doi:http://dx.doi.org/10.21013/jas.v5.n1.p7

(C) Institute of Research Advances

(cc) Br-No

This work is licensed under a Creative Commons Attribution-Non Commercial 4.0 International License subject to proper citation to the publication source of the work.

Disclaimer: The scholarly papers as reviewed and published by the Institute of Research Advances (IRA) are the views and opinions of their respective authors and are not the views or opinions of the IRA. The IRA disclaims of any harm or loss caused due to the published content to any party. 


\section{ABSTRACT}

Herbal drug therapy is regarded as an important alternative for the treatment of chronic and infectious disease. Ocimum gratissimum has been used extensively in traditional medicine in many countries. The aim of this study was to evaluate antioxidant status and antimicrobial activity of the methanol extract of Ocimum gratissimum (MEOG) and to establish that the antimicrobial activity is due to its antioxidant potentials. The total antioxidant status was evaluated using DPPH and ABTS assays and the FolinCiocalteu reagent method to determine total phenolic content of the MEOG. The antimicrobial effect was determined by agar diffusion and broth dilution method against different ATCC strains of pathogenic bacteria. Zones of inhibition, minimum inhibitory (MIC) and minimum bactericidal concentrations $(M B C)$ were determined. The results indicate that the antioxidant potential and antimicrobial activity of MEOG is mainly due to its total phenolic content and bioactive ingredients like tannins, flavonoids, saponins, phenols, quinones and terpenoids. The MEOG was found microbicidal against all tested gram positive and negative organisms and against the fungus, Candida albicans. The MIC for gram positive organisms ranged between $0.117-7.5 \mathrm{mg} / \mathrm{ml}$ and for gram negative organisms the range were between $0.469-3.75 \mathrm{mg} / \mathrm{ml}$. The $\mathrm{MBC}$ for the gram positive bacteria ranged from $0.117 \mathrm{mg} / \mathrm{ml}-15 \mathrm{mg} / \mathrm{ml}$ and for gram negative bacteria from $3.75 \mathrm{mg} / \mathrm{ml}-15 \mathrm{mg} / \mathrm{ml}$. In conclusion, MEOG can be used in the treatment of skin infections due to bacteria and fungus and also in the respiratory and gastro intestinal infections due to its antioxidant properties.

KEY WORDS: Methanol extract of Ocimum gratissimum(MEOG), antioxidant potential, total phenolic content (TPC), zone, of inhibition, minimum inhibitory concentration (MIC), minimum bactericidal concentration(MBC).

\section{Introduction}

The study on medicinal plants is essential to promote the proper use of herbal medicine in order to determine their potential as a source for new drugs. Some plants serve as source of medicines, which are useful in treatment of various categories of human ailment and conditions. World Health organization (WHO) has estimated that up to $80 \%$ of the world's population relies on plants for their primary health care (Ekpo et al., 2009). The use of plant extracts and phyto-products is gaining attention due to their availability, cost effectiveness, proven nature of specificity, biodegradability, low toxicity, and minimum residual toxicity in the ecosystem (Ogbo and Oyibo, 2008).

For a long period of time, plants have been a valuable source of natural products for maintaining human health, especially in the last decade, with more intensive studies devoted to natural therapies. The use of plant extracts and phytochemicals derived from medicinal plants are extensively used for pharmaceutical purposes. Therefore such plants should be investigated to better understand their properties, safety and efficiency. Recent studies confirm the presence of antioxidants in many medicinal plants that could be therapeutically beneficial to control the activity of harmful microbes (Mukherjee, 2002).

The indiscriminate use of commercially available antibiotics for the treatment of infectious diseases developed multiple drug resistance in the microorganisms, putting new challenge before the drug industries for identification of new efficient antimicrobial compounds. Herbal drug therapy is regarded as an important alternate, leading the researchers to focus and evaluate the traditionally recommended medicinal plants for their efficacy in various disease conditions (Kumar et al., 2005).

Basil is among the most popular of herbs grown in gardens and spice cabinets all over the world. It is an important constituent of many Ayurvedic cough syrups and expectorants, and called the "wonder herb" (Darrah, 1980). The genus Ocimum, (Lamiaceae formerly Labiatae), collectively called basil has long been recognized as a diverse and rich source of essential oils. Ocimum contains between 50 to 150 species of herbs and shrubs from the tropical regions of Asia, Africa, and Central and South America (Vieira and Simon, 2000). 
This is a highly branched herb with ribbed stem, simple leaves oppositely arranged with terminal inflorescence. The inflorescence bears white flowers and the plant is perennial.

It is widely used for treatment of nasal congestion, cough and abdominal pain. It is well known for its anti-inflammatory antimicrobial and hypoglycemic activity (Chaturvedi and George, 2007, El-Said.F, 1969, and Iwalokun, 2003). Recent studies on Ocimum gratissimum proved to be a useful medication for people living with Human Immuno deficiency Virus (HIV), and Acquired Immuno Deficiency Syndrome AIDS (Elujoba. AA,2000).

Hence, given the importance of this species of Ocimum, the current study will be evaluating the phytochemicals, total phenolic content, antioxidants and antimicrobial activities of methanol extract of Ocimum gratissimum (MEOG) against clinically important pathogens.

\section{Materials and Methods}

\subsection{Collection and identification of plants}

Tender aerial parts of $O$. gratissimum were collected locally from Botswana and the identification of the plants was done by Dr. M. P. Setshogo at the University of Botswana Herbarium (UCBA) as Ocimum gratissimum. The voucher specimen were submitted in the herbarium and voucher number were $(2006 / \mathrm{G}$, A01).

\subsection{Preparation of the methanol extract}

The plant was cut into small pieces, dried in the shade, coarsely powdered and soaked in $70 \%$ methanol for three days at room temperature. The extract was filtered and made solvent free by using a Buchi type rotary evaporator $\left(65^{\circ} \mathrm{C}\right.$ ) and dried completely in the vacuum. The yields were $7.8 \%$. The extract obtained was used to carry out the experiments as MEOG.

\subsection{Chemicals}

All the chemicals used were analytical grade and bought from Sigma-Aldrich Chemical Company, (St. Louis, MO) USA. Reagents DPPH (2,2-diphenyl-1-picrylhydrazyl) reagent [ molecular formula C18H12N5O6 molecular weight $394 \mathrm{~g} / \mathrm{mol}$ ] was purchased from Fluka Chemicals (Steinheim, Germany), and Folin-Ciocalteau reagent from Rochelle Chemicals (South Africa). Ascorbic acid and anhydrous sodium carbonate were all analytically pure and were purchased from Unilab (South Africa). Gallic acid (AR) was obtained from Sigma Chemicals (Steinheim, Germany). The solvents used for the extraction process were also of analytical grade. The TLC sheets were ready made, aluminium backed and coated to a thickness of $0.25 \mathrm{~mm}$ with silica gel $60 \mathrm{~F} 254$.

\subsection{Phytochemical screening}

The phytochemical tests were carried out in duplicates as previously detailed elsewhere and briefly described here (Mazimba,O, et al., 2015).

\subsubsection{Flavonoids}

The extract $(1 \mathrm{~mL})$ was added to a concentrated sulphuric acid $(0.2 \mathrm{~mL})$ and $0.5 \mathrm{~g}$ of $\mathrm{Mg}$. A pink or red coloration that disappear on standing $(3 \mathrm{~min}$.) indicated the presence of flavonoids. OR, Lead acetate solution $(10 \%)$ drops were added to the extract $(1 \mathrm{~mL})$. Formation of a yellow precipitate showed the presence of flavonoids.

\subsubsection{Tannins}

The extract $(1 \mathrm{~mL})$ was added to $2 \mathrm{~mL}$ of water followed by drops of dilute ferric chloride solution $(0.1 \%)$. A green to blue-green (cathechic tannins) or a blue-black (gallic tannins) coloration were positive indicators. 


\subsubsection{Saponins}

The extract $(1 \mathrm{~mL})$ was shaken vigorously with distilled water. A stable persistent froth for 20 min. was a positive indicator.

\subsubsection{Coumarins}

$\mathrm{NaOH}(2 \mathrm{~mL}, 10 \%)$ was added to $1 \mathrm{~mL}$ of extract and formation of yellow color indicates the presence of coumarins.

\subsubsection{Terpenoids}

The extract $(2 \mathrm{~mL})$ was added to acetic anhydride $(2 \mathrm{~mL})$ and concentrated $\mathrm{H}_{2} \mathrm{SO}_{4}$ drops. Formation of blue, green rings indicated the presence of terpenoids.

\subsubsection{Fatty acids}

The extract $(0.5 \mathrm{~mL})$ was mixed with $5 \mathrm{~mL}$ of ether. The solution was allowed to evaporate on filter paper. The appearance of transparence on dried filter paper indicated the presence of fatty acids.

\subsubsection{Phenols}

Ferric chloride test, an extract $(1 \mathrm{~mL})$ was treated with drops of ferric chloride $(5 \%)$ and observed for the formation of deep blue or black colour.

\subsubsection{Amino acids and Proteins}

The extract $(1 \mathrm{ml})$ was treated with drops of ninhydrin solution (1\% ninhydrin solution) and placed in a boiling water bath for 2 minutes. The formation of purple colour was a positive test.

\subsubsection{Quinones}

An extract $(1 \mathrm{~mL})$ was treated with conc. $\mathrm{HCl}$ drops and observed for the formation of yellow precipitate or coloration.

\subsubsection{Oxalate}

The extracts $(2 \mathrm{~mL})$ were treated with a few drops of glacial acetic acid. A greenish black coloration indicates presence of oxalates.

\subsection{ANTIOXIDANT STATUS}

\subsubsection{TLC - Semi Quantitative DPPH Assay}

$0.2 \%$ DPPH solution in methanol was prepared and kept in the fridge for further use. The grid space was marked with $1.0 \mathrm{~cm}^{2}$ space on an aluminum based TLC sheet (Merck silica gel $60 \mathrm{~F}_{254}$ ) and a stock solution of all the extracts together with the standard were prepared in methanol. A series of dilutions of the stock together with the standard were prepared ranging from $400 \mu \mathrm{L}$ to $0.01 \mu \mathrm{L}$ for the last dilution. The grid on the TLC sheet was labeled with extract on the horizontal axis and amount of extract on the vertical axis. The extracts of different concentrations and the standards were plotted on the TLC sheets and the spots allowed to dry for at least 2 hours. Care was taken to keep the volume of the extracts spotted the same so that all the spots were of the same size for a fair comparison. The sheet was sprayed with $0.2 \%$ DPPH solution and the appearance of yellow spots against the white background showed the antioxidant activity. Photographs of the TLC were taken after 2 hours, 6 hours, and 24 hours and this could be used for further references because the DPPH gets faded with time. This procedure was adapted and revised from the methods which were previously used by Juma and Majinda (2004).

\subsubsection{Spectrophotometric Method}

The free radical scavenging activity was measured using DPPH method modified by Yeboah and Majinda (2009). Solutions of $500 \mu \mathrm{M}$ DPPH (i.e. $0.02 \%$ or $0.2 \mathrm{mg} / \mathrm{mL}$ ) in methanol (AR) was prepared. Also 
different concentrations of each of the plant extracts and standards were prepared (ascorbic acid and gallic acid) ranging from $0.001-0.05 \mathrm{mg} / \mathrm{mL}$ in methanol. Each extract or standard solution $(2 \mathrm{~mL})$ was added to an equal volume of the DPPH solution, making a total reaction volume of $4 \mathrm{~mL}$. A control reaction mixture was prepared consisting of $2 \mathrm{~mL}$ methanol without extract and an equal volume of DPPH solution. The test tubes were tightly closed, vigorously shaken and placed in a dark cupboard for 30 minutes. The absorbance of each solution was measured at $517 \mathrm{~nm}$, and methanol was used as the blank for baseline correction, after $2 \mathrm{~h}$ and finally after $24 \mathrm{~h}$. The percentage inhibition of DPPH, (I \%) was calculated using the following formula:

$\mathrm{I} \%=($ Absorbance control- Absorbance sample $) \times 100$

Absorbance control

From the inhibition curves (I \% versus sample concentration in $\mu \mathrm{g} / \mathrm{mL}$ ) the concentration of extract or standard required to inhibit $\mathrm{DPPH}$ radical activity by $50 \%\left(\mathrm{IC}_{50}\right)$ was determined from non-linear regression equations that best fitted the curves. The experiment was carried out in triplicate and the $\mathrm{IC}_{50}$ values reported as the average of three trails in $\mu \mathrm{g} / \mathrm{mL}+$ the standard deviation.

\subsubsection{Total phenolic content}

The total phenolic content (TPC) of the extracts was determined using the Folin-Ciocalteu reagent method as described by Yeboah and Majinda (2009). Five different concentrations of the standard, gallic acid, in methanol were prepared ranging from 0.01 to $0.05 \mathrm{mg} / \mathrm{mL} .5 \mathrm{~mL}$ of $90 \%$ aqueous methanol and $0.5 \mathrm{~mL}$ Folin-Ciocalteu reagent were added to $0.5 \mathrm{~mL}$ of each of the standard solutions and to $0.5 \mathrm{~mL}$ of each extract solution $(1 \mathrm{mg} / \mathrm{mL})$ in screw cap test tubes. After $3 \mathrm{~min}, 1 \mathrm{~mL}$ of $2 \% \mathrm{Na}_{2} \mathrm{CO}_{3}$ was then added to each test-tube and the mixture was vigorously shaken for 2 minutes and left to stand for 2 hours at room temperature. The absorbance of the supernatant solution was determined at $725 \mathrm{~nm}$ using $90 \%$ aqueous methanol as a solvent blank. A gallic acid standard curve was prepared and the equation derived by linear regression $(\mathrm{y}=36.84 \mathrm{x}+0.1069)$ was used to determine the TPC of each extract in $\mathrm{mg}$ of gallic acid equivalents/g of extract (mg GAE/g). The experiment was performed in triplicate and TPC was reported as the average value of 3 trials \pm the standard deviation

\subsubsection{2, 2-Azobis-3-ethyl benzothiazoline-6-sulphonic acid (ABTS) radical scavenging activity}

ABTS radical scavenging activity was determined by the method described by Pellegrini et al., (1999). The ABTS radical cations are produced when ABTS $(7 \mathrm{mM})$ reacts with potassium persulfate $(2.45 \mathrm{mM})$ when incubated at room temperature in the dark for $16 \mathrm{hrs}$. The solution thus obtained was further diluted with phosphate buffer saline (PBS) to give an absorbance of 1.000. Different concentrations of the test sample in $50 \mu \mathrm{l}$ were added to $950 \mu \mathrm{l}$ of ABTS working solution to give a final volume of $1 \mathrm{ml}$. The absorbance was recorded immediately at $734 \mathrm{~nm}$. Gallic acid was used as reference standard. Inhibiting concentrations of extracts were tested at 2.5, 5, 10, 25, 50 and $100 \mu \mathrm{g} / \mathrm{ml}$. Reference standard (gallic acid) was tested at $1,2,4,8$ and $16 \mu \mathrm{g} / \mathrm{ml}$. The percent inhibition was calculated from the following equation: $\%$ inhibition $=[($ Absorbance of control - Absorbance of test sample $) /$ Absorbance Control $] \times 100$.

\subsection{Antimicrobial activity}

\subsubsection{Microbial cultures}

ATCC strains of microorganisms for testing the antimicrobial activity were obtained from Department of Microbiology, School of Allied Medical Sciences, University of Botswana, Botswana. The microorganisms included Gram positive cocci : Staphylococcus aureus (ATCC 25923), Methicillin resistant Staphylococcus aureus (ATCC 43300), Staphylococcus aureus from a patient sample, Staphylococcus epidermidis (ATCC 12228) and Streptococcus agalactiae (ATCC 27956), Gram positive bacilli: Listeria monocytogenes, Gram negative bacilli: Escherichia coli (ATCC 10536), Klebsiella 
pneumonia (ATCC700803), Proteus mirabilis (ATCC 25933), Pseudomonas aeruginosa(ATCC 27853), Salmonella typhimurium(ATCC 43300) and a fungus: Candida albicans(ATCC 90028). All organisms were tested for purity and maintained in nutrient agar plates (OXOID).

\subsubsection{Antimicrobial susceptibility testing}

The methanol extract of O.gratissimum was dissolved in 10\% dimethyl sulfoxide (DMSO) to give a final concentration of $2 \mathrm{gm} / 10 \mathrm{ml}$. Antimicrobial susceptibility testing to the different microorganisms was carried out by well diffusion and disc diffusion methods on Mueller Hinton agar plates (MHA) (MAST) with some modification (Coyle M.B, 2005). Using the base of a glass pasteur pipette, sterilized by the hot flame from the bunsen burner, $6 \mathrm{~mm}$ diameter wells were made in the MHA agar plate for carrying out the well diffusion method. Lawn cultures of each of the bacterial suspensions in Tryptone Soya broth (OXOID), adjusted to $0.5 \mathrm{McFarland}$ standard turbidity, (equivalent to a bacterial suspension of $1.5 \times 10^{8}$ colony forming units per $\mathrm{ml}(\mathrm{CFU} / \mathrm{ml}))$, were made on the MHA plates. 100 microliters $(\mu \mathrm{l})$ of the extract which gives a concentration of $20 \mathrm{mg}$, was added to each well. DMSO $(100 \mu \mathrm{l})$ was also added to the wells in each plate as the control. The tests were done in duplicates.

For disc diffusion method, $6 \mathrm{~mm}$ diameter discs were prepared from Whatman ${ }^{903}$ filter paper. These discs were saturated with $20 \mu \mathrm{l}(4 \mathrm{mg})$ of the extract and applied on lawn cultures of each of the bacterial suspensions on MHA plates. Ampicillin $(10 \mu \mathrm{g})$ (Mast Diagnostics) discs were used as the positive control for each of the organism, meropenem $(10 \mu \mathrm{g})$ (Mast Diagnostics) for Staphylococcus aureus (ATCC

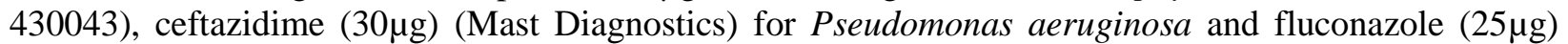

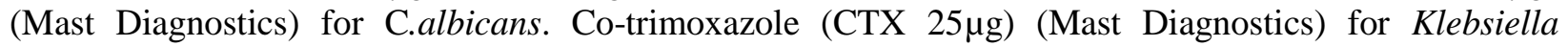
pneumonia. 20 $\mu 1$ of DMSO was added as the negative control.

The plates were incubated at $37^{\circ} \mathrm{C}$ in ambient air for 24 hours and zones of inhibition measured using a vernier calipers. The tests were done in duplicates.

\subsubsection{Minimum Inhibitory Concentration}

Minimal inhibitory concentration (MIC) was also determined for each of the microorganisms to the extracts by a micro well dilution method with some modifications (Coyle M.B, 2005). 96 -well plates were used for the assay. The 96 well plates were first prepared by adding $300 \mu \mathrm{l}$ of the $1 \mathrm{gm} / 10 \mathrm{ml} \mathrm{O}$. gratissimum extract dissolved in 10\% dimethylsulfoxide (DMSO) to the first well.150 $\mu$ l of Tryptone Soya broth (TSB) was then added to all other wells.150 $\mu$ l of the extract from the first well was transferred to the next well making the dilution of the extract 1:2 and $150 \mu \mathrm{l}$ from the second well transferred to the third well and so on till a dilution of 1:512 was reached. $3 \mu 1$ of bacterial suspension was added to all the wells. The last two wells contain positive control which is the bacterial suspension $(3 \mu \mathrm{l}$ in TSB) and negative control which is the TSB $(150 \mu \mathrm{l})$ alone.

The plates were covered and incubated at $37^{\circ} \mathrm{C}$ for 24 hours and then examined for visual inhibition of growth in the wells indicated by turbidity.

The MIC was considered the lowest concentration of the sample that prevented visible growth.

The minimum bactericidal concentrations (MBC) were also determined by subculturing the suspension from all the wells on to a MHA plate and incubated at $37^{\circ} \mathrm{C}$ in ambient air for 24 hours. The MBC was defined as the lowest concentration of the compounds to inhibit the growth of microorganisms (Nakamura, C. V et al., 1999). The tests were done in duplicate.

\subsection{Statistical analysis}

All data were expressed as the mean \pm S.E and standard deviation. 


\section{Results}

\subsection{Phytochemical screening of MEOG.}

Bioactive ingredient such as tannins, flavonoids, saponins, steroids, phenols and terpenoids were detected in the plant extract of O.gratissimum (Table 1). Fatty acids amino acids and proteins were not detected in the extract.

\subsection{Antioxidant status}

\subsubsection{TLC - Semi Quantitative DPPH}

The free radical, DPPH in the extract of O.gratissimum is reduced in the presence of an antioxidant molecule, giving rise to a colorless methanol solution. Figure-1 illustrates the decrease in the concentration of DPPH radical due to scavenging ability of hydro alcoholic extract of plant and vitamin C.

\subsubsection{Spectrophotometric method}

The DPPH radical is considered to be a model of lipophilic radical. A chain reaction in lipophilic radicals was initiated by lipid autoxidation. The radical scavenging activity of $O$. gratissimum was determined from the reduction in absorbance at $517 \mathrm{~nm}$ due to scavenging of stable DPPH free radical. The positive DPPH test suggests that the samples posses' free radical scavenging activities. The scavenging effects of O. gratissimum on the DPPH radical is illustrated and compared in Fig 2.

\subsubsection{Total phenolic content}

In the extracts used, TPC was calculated from the linear regression equation of the standard curve $y$ $=36.84 x+0.1069$ as illustrated in Fig 3 . From this equation the equivalent concentration of gallic acid $254.21 \pm 0.43 \mathrm{mg} \mathrm{mL}$ was determined for each extract and converted to $\mathrm{mg}$ of gallic acid equivalents/g of dry extract (mg GAE/g).

\subsubsection{ABTS radical scavenging activity}

The method used for the screening of antioxidant activity is reported as a decolorisation assay applicable to both lipophilic and hydrophilic antioxidants. The influences of both the concentration of antioxidant and duration of reaction are taken into account when determining the antioxidant activity (Fig 4).

\subsection{Antimicrobial activity}

The activity of methanol extract of O.gratissimum against the different microorganisms was examined and their potency was qualitatively and quantitatively assessed by the presence or absence of inhibition zones, zone diameter (Table 2), MIC values and MBC values (Table 3).

The disc diffusion was done with $20 \mu \mathrm{l}$ of the extract which gave a concentration of $4 \mathrm{mg} / \mathrm{ml}$ of O.gratissimum. Hence the zone of inhibition was noted only for Streptococcus agalactiae and Staphylococcus epidermidis at a concentration of $4 \mathrm{mg} / \mathrm{ml}$. The MBC reported for these organisms is

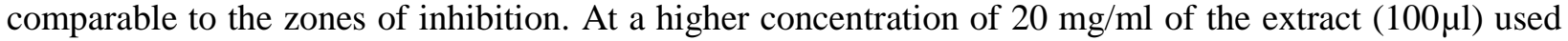
in well diffusion all pathogenic bacteria showed zones of inhibition.

O.gratissimum extract showed considerable activity against the gram positive cocci especially Streptococcus agalactiae and Staphylococcus epidermidis. The MBC for Streptococcus agalactiae and Staphylococcus epidermidis, $0.117 \mathrm{mg} / \mathrm{ml}$ and $1.875 \mathrm{mg} / \mathrm{ml}$ were lower compared to that of the other organisms with MBC ranging from $3.75 \mathrm{mg} / \mathrm{ml}-15 \mathrm{mg} / \mathrm{ml}$ (Table3).

The MIC for gram positive organisms ranged between $0.117-7.5 \mathrm{mg} / \mathrm{ml}$ and for gram negative organisms the range were between $0.469-3.75 \mathrm{mg} / \mathrm{ml}$. 
The MBC for the gram positive bacteria ranged from $0.117 \mathrm{mg} / \mathrm{ml}-15 \mathrm{mg} / \mathrm{ml}$ and for gram negative bacteria from $3.75 \mathrm{mg} / \mathrm{ml}-15 \mathrm{mg} / \mathrm{ml}$.

The solvents used for the dilutions were also tested for antimicrobial activity and was found to have no inhibitory activity.

\section{Discussion}

The increasing interest in natural products present in medicinal plants used in traditional medicine have placed medicinal plants on front line as one of the dependable sources of potential antimicrobial agents and possibly for discovery of novel drugs. Owing to the side effects and the resistance that pathogenic microorganisms build against antibiotics, many scientists have started paying attention to medicinal plants and biologically active compounds isolated from plant species used in herbal medicine (Khare, 2007)

Medicinal plants are an enormous source of alternative antimicrobial therapy, particularly in the face of emerging resistance against orthodox antimicrobial drugs. From time immemorial, many plants have been used by man as source of treatment of various disease conditions particularly at the community level. These covered wide variety of therapeutic practices that varied from country to country. These plants are referred to as alternative or complimentary medicines (Joshy, 2013).

Animal body is equipped with antioxidant defense system that deactivates the highly reactive free radicals, through the activities of antioxidants enzymes and antioxidants. Free radicals have aroused significant interest among scientists in the past decade. Their broad range of effects in biological systems has drawn the attention of many experimental works. It has been proved that these mechanisms may be important in the pathogenesis of certain diseases and ageing. There are many reports that support the use of antioxidant supplementation in reducing the level of oxidative stress and in slowing or preventing the development of complications associated with diseases (Valco et al., 2007).

This study evaluated the phytochemicals, total phenolic content, antioxidants and antimicrobial activities of MEOG against different pathogens causing skin, respiratory and gastrointestinal tract infections.

\section{Phytochemicals:}

The presence of flavonoids, tannins, terpenoids and phenols are associated with medicinal values such as the anti-inflammatory, antidiabetic, analgesic and antimicrobial activities. Methanol, a polar solvent, extracts more polar components together with the non-polar constituents of the plant; hence it shows better antioxidant activities. Studies have shown that fruit and vegetable possess a large spectrum of biological activities that are principally due to their antioxidant property. These control reactive oxygen species from exogenous factors and thus prevent free radical damage and lipid peroxidation. Many synthetic antioxidant components have shown toxic and/or mutagenic effects, which have shifted the attention towards the naturally occurring antioxidants. Flavonoids and other phenolic compounds of plant origin have been reported as scavengers and inhibitors of lipid peroxidation. More than 4000 phenolic compounds (flavonoids, mono-phenols and polyphenols) are found in vascular plants (Slinkard,1997) .A phenolic compound have been shown to possess remarkable antioxidant properties due to its redox properties which enable them to act as free radical scavengers and inhibits lipid peroxidation. One method of assessing the antioxidant potential of the plant is to determine the total phenolic content. Generation of the ABTS radical cation forms the basis of one of the spectrophotometric methods that have been applied to the measurement of the total antioxidant activity of solutions of pure substances. The results of the phytochemical study indicate that the extracts could significantly scavenge the level of oxidants beneficially with the improvement of the antioxidant system (Rice Evans et al., 1995). DPPH is a free radical, reduced in the presence of an antioxidant molecule. Figure: 2 and 3 illustrate the decrease in the concentration of DPPH radical due to scavenging ability. Vitamin $\mathrm{C}$ and Gallic acid were used as standards to compare the effects of the extracts with DPPH which is comparable to the reported value of Thabrew et al., (1998). 


\section{Antimicrobial activity:}

The antimicrobial activity of the methanol extract of O.gratissimum on the test organisms is reported in this study which is in contrast to the study by Junaid et al., (2006), which found methanol extracts were resistant to all of the organisms tested except E.coli. But the results are in confirmation with all other studies that show sensitivity of methanol extract to microorganisms (Ogunniran, K. O. (2009), Mann, A. (2012)). Another study done by Okigbo and Mmeka (2006), reported no activity of ethanol extract of O.gratissimum against C.albicans .Our study showed that the methanol extract of O.gratissimum had antifungal activity and the MBC was $3.75 \mathrm{mg} / \mathrm{ml}$. Similar antifungal activity was observed by Nwosu and Okafor (1995), against dermatophytes. As observed by Junaid S.A et al., (2006), the MBC values are more reliable than the MIC values which depends only on the visual observation of turbidity.

The antimicrobial activity of the extract is due to the presence of the different phytochemicals especially the flavonoids which can complex with bacterial cell wall and disrupts the membrane integrity. Tanins have been reported to inhibit microbial adhesion enzymes and cell envelope proteins (Mann.A, 2012). The phenolic component can cause leakage of intracellular ATP and potassium ions leading to bacterial cell death. The difference in the susceptibility of Gram positive and Gram negative bacteria to the extract of O.gratissimum is probably because of the difference in the outer membrane structure of the Gram positive and Gram negative bacterial cell wall as reported also by other studies done by Joshi RK (2013), and Ogunniran, K. O (2009). Gram negative bacteria have a hydrophilic outer membrane which blocks penetration of hydrophobic compounds into the cell membranes. These phytochemicals may be responsible for the medicinal value of $O$. gratissimum.

\section{Conclusion}

The WHO has provided guidelines that will aid countries to develop and utilize their indigenous medicines for their national health agenda. Our study also justifies the traditional medical uses of $O$. gratissimum for treating diseases like diarrhoea, skin infections and respiratory tract infection. Further studies to determine the appropriate concentration and dose that can be administered safely to patients and the side effects that these extracts can produce is warranted.

\section{Acknowledgment}

Authors are thankful to the Office of Research and Development of the University of Botswana for providing funds to carry out this study. We are also thankful to the School of Allied Medical Sciences, Faculty of Health Sciences, University of Botswana, for permission to conduct the study in the lab.

\section{REFERENCES}

Chaturvedi, P., George, S., John, A. (2007).Preventive and protective effects of wild Basil in ethanol induced liver toxicity in rats. British Journal of Biomedical Science. 64:1: 10-12.

Coyle, M. B. (2005). Manual of antimicrobial susceptibility testing. American Society for Microbiology.

Darrah, H.H. (1980). The cultivated basils. Buckeye Printing Company

Ekpo M.A., Etim P.C., (2009). Antimicrobial activity of ethanolic and aqueous extracts of Sidaacutaon microorganisms from skin infections. J Med Plant Res 3(9):621-624. Encyclopedia Britannica, 2010 Anthelmintic. Encyclopedia Britannica Ultimate Reference Suite, Chicago.

El-said, F., Sofowora, E. A., Malcolm, S.A., Hofer, A. (1969). An investigation into the efficacy of Ocimum gratissimum as used in Nigeria native medicine. Planta Medica. 97: 195-200.

Elujoba, A.A. (2000). Studies on the antidiarrhoea activity of Ocimum gratissimum. University of Ile Ife Press. 
George, S. and Chaturvedi, P. (2008). Protective role of Ocimum canum (OCM) plant extract on alcohol induced oxidative stress in albino rats. British Journal of Biomedical Sciences. 65.2:80-5.

Iwalokun, R.A., Gbenle, G.O., Adewole, T.A., Smith, S.I., Akinsinde, K.A., Omonigbehin, E.O. (2003). Effects of Ocimum gratissimum L. essential oil at sub-inhibitory concentration on virulent and multidrug resistance Shigella strains from Lagos, Nigeria, APMIS. 3.4: 477-482.

Joshi, R. K. (2013). Chemical composition, in vitro antimicrobial and antioxidant activities of the essential oils of Ocimum gratissimum, O. sanctum and their major constituents. Indian journal of pharmaceutical sciences, 75(4), 457.

Juma BF, Majinda RRT. 2004. Erythrinaline alkaloids from the flowers and pods of Erythrinalyistemon and their DPPH radical scavenging properties. Phytochemistry, 65: 1397-1404.

Junaid, S. A., Olabode, A. O., Onwuliri, F. C., Okwori, A. E. J., \& Agina, S. E. (2006). The antimicrobial properties of Ocimum gratissimum extracts on some selected bacterial gastrointestinal isolates. African journal of Biotechnology, 5(22).

Kumar, R.S., Sivakumar, T., Sunderam, R.S., Gupta, M., Mazumdar, U.K Gomathi, P., Rajeshwar, Y. , Saravanan, S. Kumar, M.S. Murugesh , K.and Kumar. K. A. (2005). Antioxidant and antimicrobial activities of Bauhinia racemosa L. stem bark. Brazilian Journal Medicine and Biology Research.38.7 $: 1015-1024$.

Khare CP. 2007.Indian Medicinal Plants, An Illustrated Dictionary. Berlin: Springer.

Mann, A. (2012). Phytochemical constituents and antimicrobial and grain protectant activities of clove basil (Ocimum gratissimum L.) grown in Nigeria. International Journal of Plant Research, 2(1), 51-58.

Mazimba, O., Wale, K., Kwape, T. E., Mihigo, S. O., \& Bokolo, M. K. (2015). Cinnamomum verum: Ethylacetate and methanol extracts antioxidant and antimicrobial activity. J Med Plants Studies, 3(3), 2832.

Mukherjee, P.K. (2002). Quality Control of Herbal Drugs - An Approach to Evaluation of Botanicals. Business Horizons, and New Delhi, India; Pharmacological screening of herbal drugs. 519-582

Nakamura, C. V., Ueda-Nakamura, T., Bando, E., Melo, A. F. N., Cortez, D. A. G., \& Dias Filho, B. P. (1999). Antibacterial activity of Ocimum gratissimum L. essential oil. Memórias do Instituto Oswaldo Cruz, 94(5), 675-678.

Nwosu, M. O., \& Okafor, J. I. (1995). Preliminary studies of the antifungal activities of some medicinal plants against Basidiobolus and some other pathogenic fungi. Mycoses, 38(5-6), 191195.

Ogbo EM, Oyibo AE.( 2008 ). Effects of three plant extracts (Ocimum gratissimum, Acalypha wilkesiana and Acalypha macrostachya) on post- harvest pathogen of Persea americana. Journal of Medicinal Plants Research. Nov 30;2(11):311-4.

Ogunniran, K. O. (2009). Antibacterial effects of extracts of Ocimum gratissimum and piper guineense on Escherichia coli and Staphylococcus aureus. African Journal of Food Science, 3(3), 77-81.

Okigbo, R. N., \& Mmeka, E. C. (2006). An appraisal of phytomedicine in Africa. KMITL Sci. Technol. J, 6(2), 83-94. 
Re, R., Pellegrini, N., Proteggente, A., Pannala, A., Yang, M., \& Rice-Evans, C. (1999). Antioxidant activity applying an improved ABTS radical cation decolorization assay. Free radical biology and medicine, 26(9), 1231-1237.

Slinkard, K., Singleton, V.L. (1977). Total phenol analyses; automation and comparison with manual methods. American Journal of Enology and Viticulture, 28: 49-55.

Thabrew, M.I., Hughes, R.D., Mc Farlane, I.G. (1998). Antioxidant activity of Osbeckia aspera. Phytotherapy Research.12:288-290.

Rice-Evans, C.A., Miller, N.J., Bolwell, P.G., Bramley, P.M., Pridham, J.B. (1995). The relative antioxidant activity of plant derived polyphenolic flavonoids. Free Radical Research, 22: 375-383.

Vieira, R. F., J. E. Simon (2000). Chemical characterization of basil (Ocimum spp.) found in the markets and used in traditional medicine in Brazil. 54.2: 207-216.

Valko M, Leibfritz D, Moncol J, Cronin MT, Mazur M, Telser J .(2007). Free radicals and antioxidants in normal physiological functions and human disease. Int J Biochem Cell Biol. 39:44-84.

World Health Organization (2013). WHO traditional medicine strategy: 2014-2023

Yeboah, E. M., \& Majinda, R. R. (2009). Radical scavenging activity and total phenolic content of extracts of the root bark of Osyris lanceolata. Natural product communications, 4(1), 89-94. 
(Tables \& Figures)

Table-1: Phytochemical screening of MEOG

\begin{tabular}{|l|l|}
\hline Test & MEOG \\
\hline Flavonoids & + \\
\hline Tannins & + \\
\hline Saponins & + \\
\hline Coumarins & - \\
\hline Terpenoids & + \\
\hline Fatty acids & - \\
\hline Phenols & + \\
\hline Amino acids & - \\
\hline a proteins & - \\
\hline Quinones & + \\
\hline Oxalate & - \\
\hline
\end{tabular}

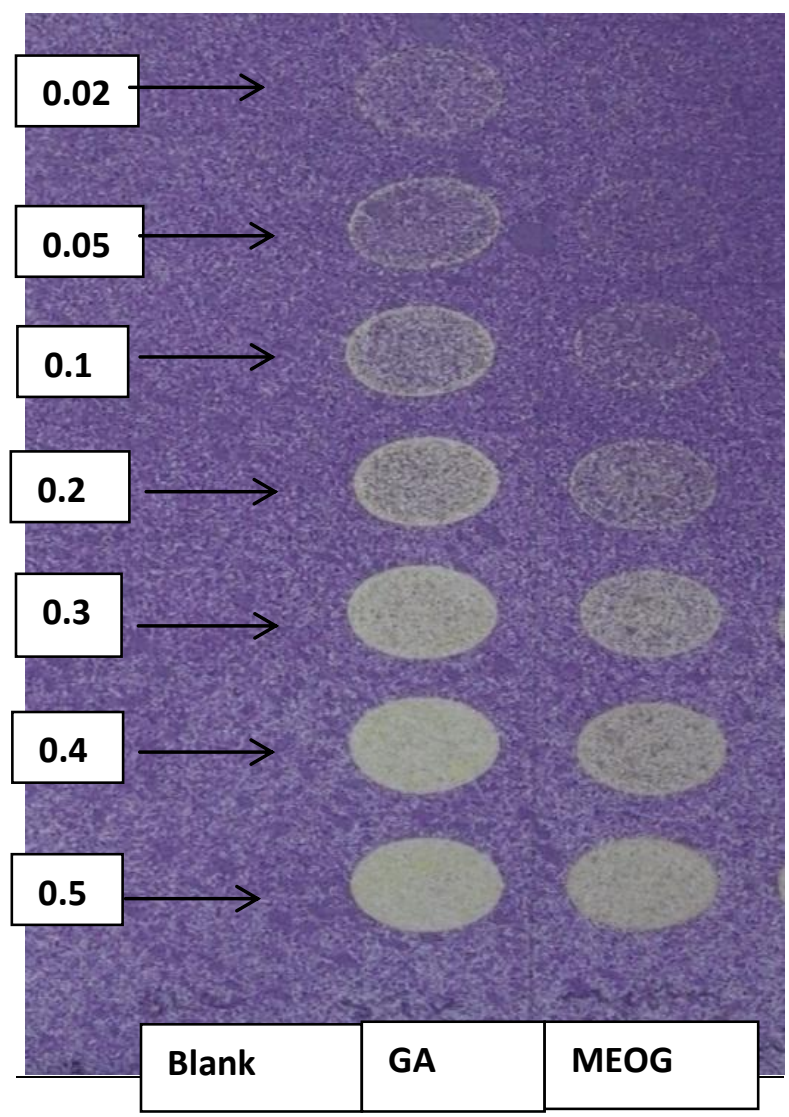

Fig 1: Semi quantitative TLC-DPPH radical scavenging activity of MEOG. 


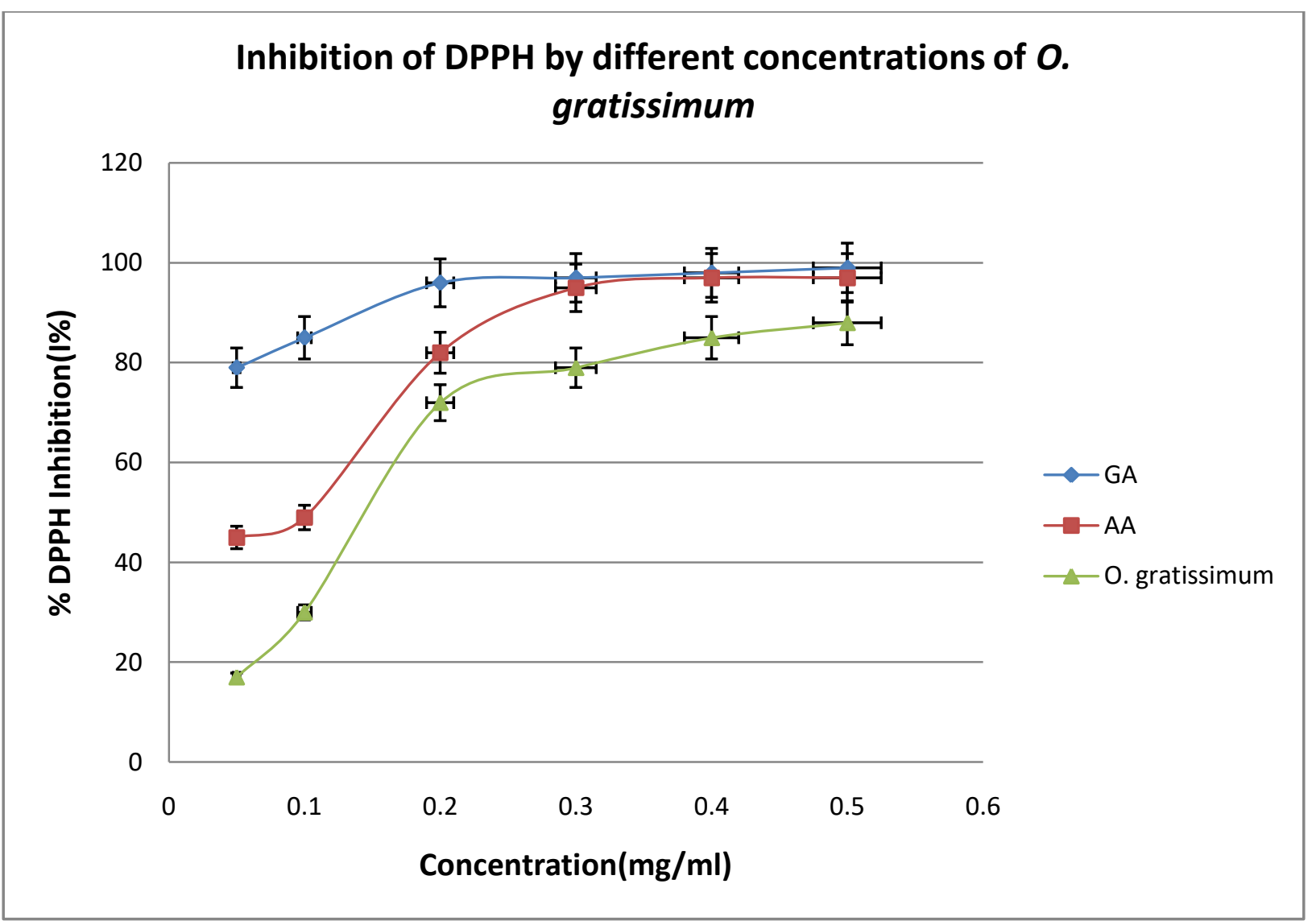

FIG 2: Radical scavenging activity of MEOG

(GA- Gallic acid, AA -Ascorbic acid, O. gratissimum- MEOG) 


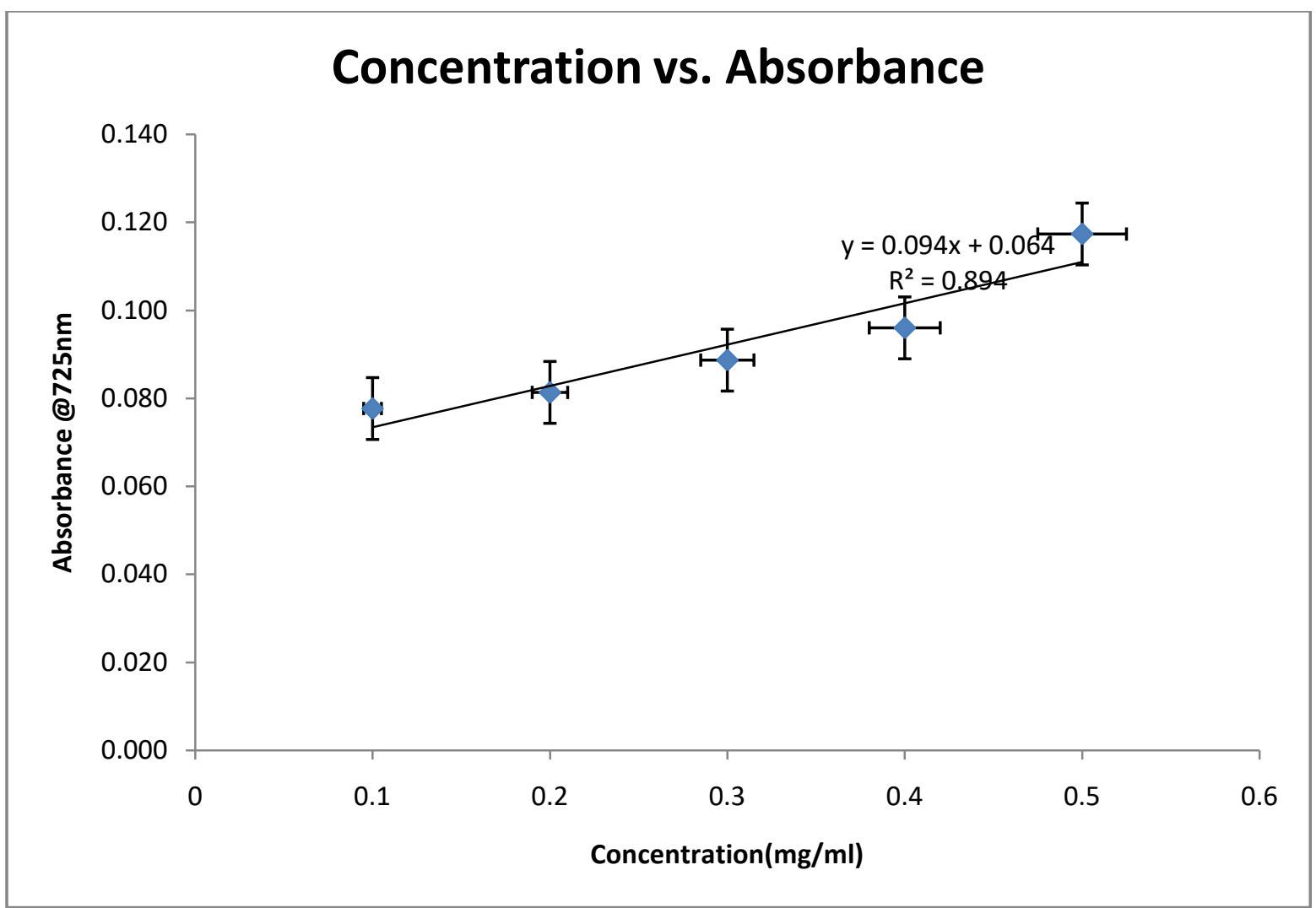

Fig 3: Total phenolic content of MEOG.

$(\mathrm{X}=(\mathrm{Y}-0.064) / 0.094 \mathrm{X} 100)$

* Values are the average of three trials \pm standard deviation. 


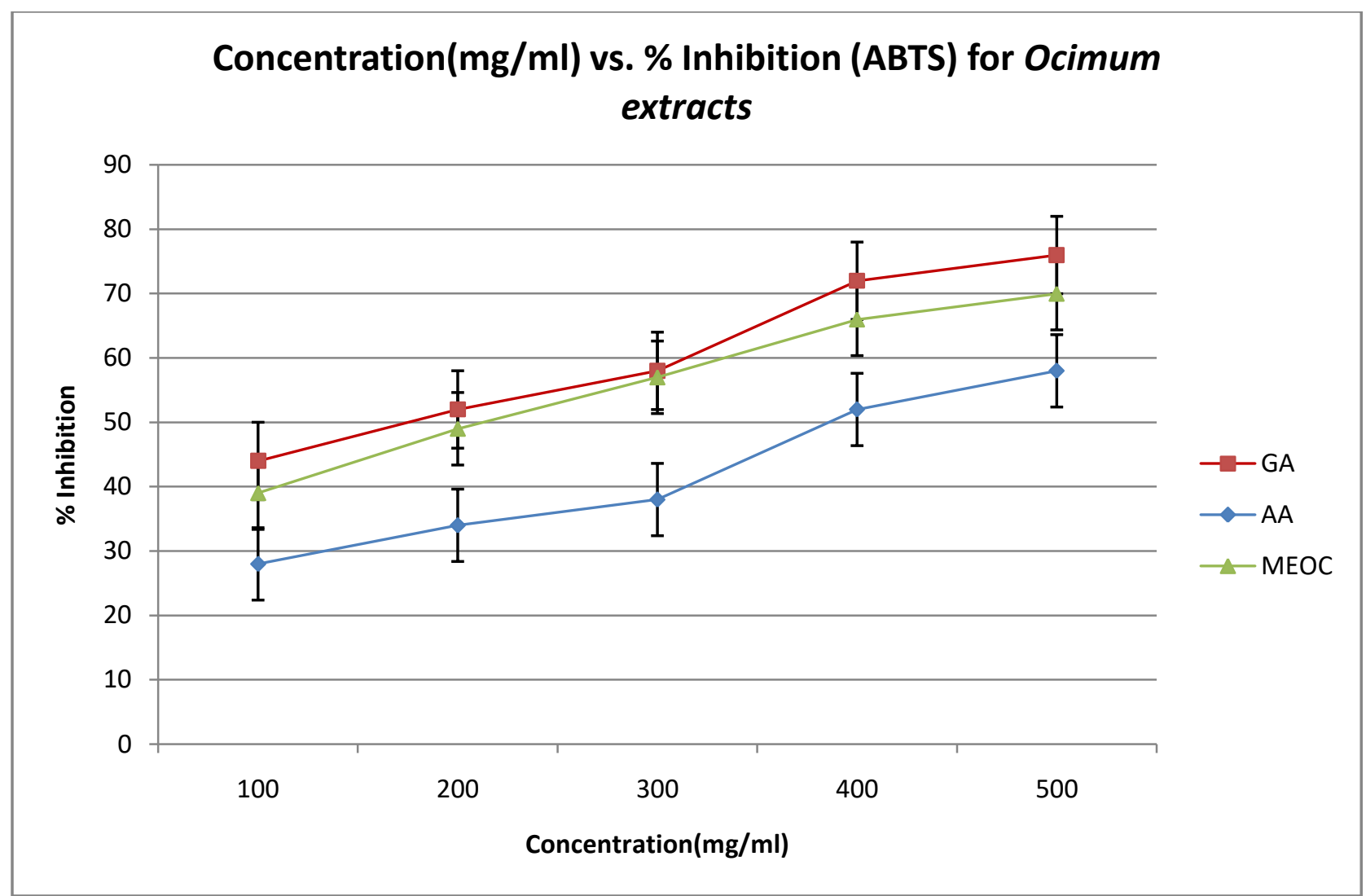

Fig 4: ABTS radical scavenging activity (GA- Gallic acid, AA -Ascorbic acid, O. gratissimum- MEOG) 
Table 2: The antimicrobial activities of methanol extract $O$. gratissimum.

\begin{tabular}{|c|c|c|c|}
\hline Organisms & $\begin{array}{l}\text { Well diffusion } \\
\text { O.gratissimum } \\
(100 \mu \mathrm{l}=20 \mathrm{mg} / \mathrm{ml} \\
\text { Zone of inhibition } \\
(\mathrm{mm})\end{array}$ & $\begin{array}{l}\text { Disc diffusion } \\
\text { O. gratissimum } \\
(20 \mu \mathrm{l}=4 \mathrm{mg} / \mathrm{ml}) \\
\text { Zone of inhibition } \\
(\mathrm{mm})\end{array}$ & $\begin{array}{l}\text { Control } \\
\text { (Ampicillin } 10 \mu \mathrm{g}) \\
\text { Zone of inhibition } \\
(\mathrm{mm})\end{array}$ \\
\hline $\begin{array}{l}\text { Staphylococcus aureus } \\
\text { (ATCC 25923) }\end{array}$ & $12.5 \pm 0.5$ & $\mathrm{NZ}$ & 33 \\
\hline $\begin{array}{l}\text { Staphylococcus aureus } \\
\text { (Methicillin resistant) } \\
\text { (ATCC 43300) }\end{array}$ & 14 & $\mathrm{NZ}$ & $29 *$ \\
\hline $\begin{array}{l}\text { Staphylococcus aureus. } \\
\text { (patient sample) }\end{array}$ & 14 & $\mathrm{NZ}$ & 26 \\
\hline $\begin{array}{l}\text { Staphylococcus epidermidis } \\
\text { (ATCC 12228) }\end{array}$ & 12 & 11 & 28 \\
\hline $\begin{array}{l}\text { Streptococcus agalactiae } \\
\text { (ATCC 27956) }\end{array}$ & 16 & 10 & 34 \\
\hline Listeria monocytogenes & 13 & $\mathrm{NZ}$ & 37 \\
\hline $\begin{array}{l}\text { Escherichia coli } \\
\text { (ATCC 10536) }\end{array}$ & 11 & NZ & 19 \\
\hline $\begin{array}{l}\text { Klebsiella pneumonia } \\
\text { (ATCC 700803) }\end{array}$ & 13 & $\mathrm{NZ}$ & $23 * *$ \\
\hline $\begin{array}{l}\text { Proteus mirabilis } \\
\text { (ATCC 12228) }\end{array}$ & 22 & $\mathrm{NZ}$ & 30 \\
\hline $\begin{array}{l}\text { Pseudomonas aeruginosa } \\
\text { (ATCC 27853) }\end{array}$ & 14 & NZ & $27 * * *$ \\
\hline $\begin{array}{l}\text { Salmonella typhimurium } \\
\text { (ATCC 14028) }\end{array}$ & 15 & $\mathrm{NZ}$ & 24 \\
\hline $\begin{array}{l}\text { Candida albicans } \\
\text { (ATCC 90028) }\end{array}$ & 11 & $\mathrm{NZ}$ & $25 * * * *$ \\
\hline
\end{tabular}


Table 3: The MIC and MBC of methanol extract $O$. gratissimum

\begin{tabular}{|c|c|c|}
\hline Organisms & $\begin{array}{l}\mathrm{MIC} \\
(\mathrm{mg} / \mathrm{ml})\end{array}$ & $\begin{array}{l}\mathrm{MBC} \\
(\mathrm{mg} / \mathrm{ml})\end{array}$ \\
\hline $\begin{array}{l}\text { Staphylococcus aureus } \\
\text { (ATCC 25923) }\end{array}$ & 0.938 & 7.5 \\
\hline $\begin{array}{l}\text { Staphylococcus aureus } \\
\text { (Methicillin resistant) } \\
\text { (ATCC 43300) }\end{array}$ & 7.5 & 15 \\
\hline $\begin{array}{l}\text { Staphylococcus aureus. } \\
\text { (patient sample) }\end{array}$ & 1.875 & 3.75 \\
\hline $\begin{array}{l}\text { Staphylococcus epidermidis } \\
\text { (ATCC 12228) }\end{array}$ & 1.875 & 1.875 \\
\hline $\begin{array}{l}\text { Streptococcus agalactiae } \\
\text { (ATCC 27956) }\end{array}$ & 0.117 & 0.117 \\
\hline Listeria monocytogenes & 0.938 & 3.75 \\
\hline $\begin{array}{l}\text { Escherichia coli } \\
\text { (ATCC 10536) }\end{array}$ & 1.875 & 3.75 \\
\hline $\begin{array}{l}\text { Klebsiella pneumonia } \\
\text { (ATCC 700803) }\end{array}$ & 0.469 & 3.75 \\
\hline $\begin{array}{l}\text { Proteus mirabilis } \\
\text { (ATCC 12228) }\end{array}$ & 0.938 & 3.75 \\
\hline $\begin{array}{l}\text { Pseudomonas aeruginosa } \\
\text { (ATCC 27853) }\end{array}$ & 0.469 & 3.75 \\
\hline $\begin{array}{l}\text { Salmonella typhimurium } \\
\text { (ATCC 14028) }\end{array}$ & 3.75 & 15 \\
\hline $\begin{array}{l}\text { Candida albicans } \\
\text { (ATCC 90028) }\end{array}$ & 0.938 & 3.75 \\
\hline
\end{tabular}

